\title{
Komparácia úrovne akceleračnej rýchlosti a explozívnej sily z hl'adiska hráčskych pozícií futbalistov reprezentácie Slovenska U21
}

\section{Level's comparison of sprint and jump abilities of soccer representative players of Slovakia $\mathrm{U} 21$ at different positions}

\author{
Pavol Pivovarniček
}

Filozofická fakulta Univerzity Mateja Bela, Banská Bystrica, Slovenská republika

\begin{abstract}
Abstrakt:
Ciel’om štúdie bola komparácia aktuálnej úrovne limitujúcich pohybových schopností - akceleračnej rýchlosti a explozívnej sily dolných končatín u futbalistov reprezentácie Slovenskej republiky U21 z hl'adiska hráčskych pozícií. Výskumný súbor tvorili hráči futbalovej reprezentácie Slovenskej republiky kategórie U21 $(N=18$, brankári $N=2$, obrancovia $N=4$, stredoví hráči $N=7$, útočníci $N=5)$ v obdobi kvalifikácie na Majstrovstvá Európy U21 2011 vo futbale. Úroveň akceleračnej rýchlosti bola diagnostikovaná zariadením Fitro Light Gates (FiTRONIC, Bratislava, Slovenská republika). Kritériom hodnotenia úrovne bol dosiahnutý čas na vzdialenost' $10 \mathrm{~m}$ s presnostou 0,01 s. Úroveň explozivnej sily dolných končatín bola diagnostikovaná zariadením FiTRO Jumper (FiTRONIC, Bratislava, Slovenská republika). Kritériom hodnotenia úrovne bola výška výskoku $v \mathrm{~cm}$ s presnostou 0,1 cm. Rozdiely v úrovni akceleračnej rýchlosti a explozívnej sily dolných končatín boli zistované a definované expertiznou vecnou analýzou. Úroveň akceleračnej rýchlosti súboru bola

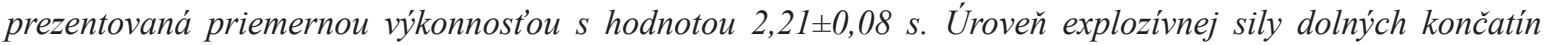

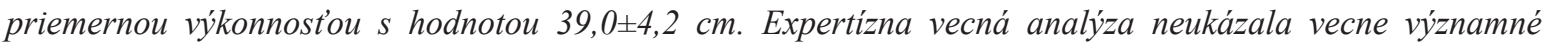
rozdiely $v$ sledovaných parametroch medzi skupinami podl'a hráčskych pozícií. Vecne významne nižšia úroveň bola zaznamenaná v úrovni akceleračnej rýchlosti len u brankárov.
\end{abstract}

\begin{abstract}
:
The aim of the study was to compare the level of limited physical abilities - sprint and jump abilities of the players of Slovak national under-21 soccer team at different positions. The observational group consisted of Slovak national under-21 soccer players $(N=18$, goalkeepers $N=2$, defenders $N=4$, midfielders $N=7$, forwards $N=5$ ) in time of qualification for the UEFA European Under-21 Football Championship 2011. The level of sprint abilities was diagnosed with the device Fitro Light Gates (FiTRONIC, Bratislava, The Slovak Republic). The criterion for the level assessment was the time obtained in the distance of $10 \mathrm{~m}$ with the exactness of $0.01 \mathrm{~s}$. The level of jump abilities was diagnosed with the device FiTRO Jumper (FiTRONIC, Bratislava, The Slovak Republic). The criterion for the level assessment was the jump height in cm with the exactness of 0.1 $\mathrm{cm}$. Differences in the level of sprint and jump abilities were recognised and defined with the special subject analysis. The level of sprint abilities of the whole group was presented with the average performance with the value $2.21 \pm 0.08 \mathrm{~s}$. The level of jump abilities with the average performance with the value $39.0 \pm 4.2 \mathrm{~cm}$. We have not found out with special subject analysis any significant differences in monitored parameters between groups divided according to playing positions. The significantly lower level was observed only in the level of sprint abilities of goalkeepers.
\end{abstract}

Kl'účové slová: bežecký čas, diagnostika, výška vertikálneho výskoku

Key words: running's time, diagnostics, height of vertical jump 


\section{ÚVOD}

Moderné trendy súčasného vrcholového futbalu sa prejavujú najmä dynamizáciou a neustálym zvyšovaním hernej rýchlosti. Z tohto dôvodu môžeme súhlasit's Nemcom, Štefaňákom \& Sylvestrom (2005), že rýchlostné a rýchlostno-silové pohybové schopnosti (explozívna sila dolných končatín) patria spolu so špeciálnou vytrvalost’ou sú limitujúcimi pohybovými schopnost'ami vo futbale. Kondícia podl’a Bunca (1999) predstavuje 30-40 \% herného výkonu. Súhlasíme s tvrdením Reillyho (1997), Psottu et al. (2006), Orendurffa et al. (2010), podl'a ktorých je futbal intermitentnou pohybovou činnost'ou, ktorá obsahuje vel'mi krátke, obvykle 1 až 5 sekúnd trvajúce intervaly zat’aženia vysokej až maximálnej intenzity, ktoré sa striedajú s intervalmi zat’aženia nižšej intenzity alebo telesného pokoja trvajúceho 5 až 10 sekúnd. Little \& Williams (2006) medzi pohybové činnosti vo vysokej intenzite zaradzujú bežeckú akceleráciu, maximálnu bežeckú rýchlost’ a agility, ktoré sa v zápase neustále vyskytujú. Z hl'adiska techniky pohybu futbalistu ide o vysokú variabilitu pohybov. Futbalista je v hre nútený využívat' rôzne typy behu (beh vpred, beh vzad) v rôznych intenzitách, vertikálne výskoky a dopady, rýchle obraty a vstávanie po pádoch, prácu s loptou aj bez lopty. Bangsbo, Mohr \& Krustrup (2006), Bangsbo, Iaia \& Krustrup (2007) uvádzajú u hráčov najvyššej úrovne 150 až 250 krátkych intenzívnych činností v zápase. Hipp (2007) uvádza, že vo futbalovom zápase môžeme pozorovat’ u hráča okolo 100 až 150 šprintov rôznej dížky. Podl'a zistení Psottu et al. (2006) je v samotnej futbalovej hre 50-65 \% všetkých realizovaných šprintov kratších ako 5 m, 75-85 \% všetkých šprintov nie je dlhších ako $10 \mathrm{~m}$ a priemerná dížka šprintov je $9 \mathrm{~m}$. Grasgruber \& Cacek (2008) uvádzajú dížku šprintov cca 15 m a spravidla nie viac ako 30 m, každých cca 90 s, čo vychádza za celý zápas 0,8 až $1 \mathrm{~km}$. Andrzejewski et al. (2012) zistili u profesionálnych hráčov európskych líg, že 90 \% všetkých realizovaných šprintov v zápasoch je do 5 sekúnd. Podl’a výskumov dosahujú profesionálni hráči významne vyššiu rýchlost' v prvých $10 \mathrm{~m}$ šprintov pri porovnaní s hráčmi nižších sút'aží (Grasgruber \& Cacek, 2008, Psotta et al., 2006). Haugen, Tønnessen \& Seiler (2013) zistili, že nórski futbaloví reprezentanti a hráči najvyššej nórskej sút’aže dosahovali z hl'adiska akceleračnej a bežeckej rýchlosti vyššiu výkonnost' ( $\mathrm{p}<$ 0,05) ako hráči 2. divízie (rozdiel 1,0-1,4 \%), 3.-5. divízie (rozdiel 3,0-3,8 \%), juniorskej reprezentácie (rozdiel 1,7-2,2 \%) a juniorských hráčov (rozdiel 2,8-3,7 \%). Ked’že sa jednalo o dlhodobý výskum (1995-2010, n = 939 , vek $=22,1 \pm 4,3$ rokov) autori mali možnost' zistit', že hráči z obdobia 2006-2010 boli v porovnaní s hráčmi 1995-1999 a 2000-2005 v behu na 20 m rýchlejší o 1-2 \% a dosahovali skôr maximálnu rýchlost'.

Podl'a Psottu et al. (2006) sa v súčasnom futbale v rámci herných systémov uplatňuje aktívne poňatie útočnej a obrannej fázy hry, ktoré je charakterizované zapojením väčšieho počtu hráčov v oboch fázach hry. Ide o rýchle presuny skupín hráčov v prechodových fázach z obrany do útoku a naopak, pohybová činnost' na vel'kej ploche ihriska, ktorá sa prejavuje priestorovým prelínaním hráčov jednotlivých blokov a horizontálne a vertikálne cirkulácie hráčov v útočnej fáze.

Uvedené štúdie poukazujú na skutočnost', že v tréningovom procese futbalistov sú potrebné stimulácie na rozvoj akceleračnej bežeckej rýchlosti a explozívnej sily dolných končatín. Aj ked' úroveň akceleračnej rýchlosti a explozívnej sily dolných končatín je geneticky determinovaná a závisí od neuromuskulárnej koordinácie a zastúpenia rýchlych svalových vláken tak je nevyhnutné zamerat'sa na stimuláciu.

Ciel’om predloženej štúdie je komparácia aktuálnej úrovne limitujúcich pohybových schopností akceleračnej rýchlosti a explozívnej sily dolných končatín u futbalistov reprezentácie Slovenskej republiky U21 z hl'adiska hráčskych pozícií.

\section{METODIKA}

Výskumný súbor tvorili hráči futbalovej reprezentácie Slovenskej republiky kategórie U21 (N=18, brankári $\mathrm{N}=2$, obrancovia $\mathrm{N}=4$, stredoví hráči $\mathrm{N}=7$, útočníci $\mathrm{N}=5$ ). Hráči tvorili družstvo bojujúce o postup na Majstrovstvá Európy vo futbale 2011 (U21) v Dánsku v 7. kvalifikačnej skupine spolu s U21 reprezentáciami Chorvátska, Srbska, Nórska a Cypru.

Výskum sme realizovali 8. 10. 2009 v dopoludňajších hodinách, kedy môžeme v súlade s Jančokovou (2000) hovorit' o prvom dennom vrchole výkonnosti. Diagnostika úrovne akceleračnej rýchlosti a explozívnej sily dolných končatín sa uskutočnila v komplexe Národného tréningového centra (NTC) v Senci pred kvalifikačným zápasom na ME s reprezentáciou Cypru U21 dňa 14. 10. 2009 v cyperskom Achnase.

Futbalisti absolvovali pred diagnostikou všeobecné rozcvičenie (10 minút) a rýchlostné rozcvičenie (10 minút).

Akceleračnú rýchlost' sme diagnostikovali zariadením FiTRO Light Gates (FiTRONIC, Bratislava, Slovenská republika) behom na $10 \mathrm{~m}$ z polovysokého štartu na futbalovom ihrisku s prírodnou trávou. Meraný 
futbalista zaujal na začiatku merania štartovú pozíciu na štartovej čiare a na zvukový signál „Hop“, ktorý bol zároveň spúšstačom merania $\mathrm{v}$ počítačovom zariadení vyštartoval. $\mathrm{V}$ rámci jedného merania futbalisti absolvovali dva pokusy. Do hodnotenia sme brali lepší z pokusov.

$\mathrm{Na}$ diagnostiku explozívnej sily dolných končatín sme použili zariadenie FiTRO Jumper (FiTRONIC, Bratislava, Slovenská republika) pozostávajúce z kontaktnej platne umiestnenej na podlahe interfejsom pripojenej na počítač. Explozívnu silu dolných končatín sme diagnostikovali vertikálnym výskokom z drepu s protipohybom a použitím švihovej práce paží (Weineck, 2007). Diagnostikovaní zaujali na zariadení pozíciu drep s predpaženými a mierne pokrčenými rukami, realizovali pohyb pažami smerom k vzpaženiu, švihli nimi a súčasne realizovali tri maximálne výskoky. Pri realizácii výskoku mal byt' odraz čo najkratší a čo najsilnejší, bez krčenia kolien a s uvol’nenými kolenami. Do hodnotenia sme brali najlepší z troch výskokov.

V prezentovanej štúdii sme $\mathrm{v}$ rámci deskriptívnej štatistiky použili z mier centrálnej tendencie aritmetický priemer (x) a z mier variability smerodajnú (štandardnú) odchýlku (SD).

Významnost' rozdielov úrovne akceleračnej rýchlosti a explozívnej sily dolných končatín sme zistovali expertíznou vecnou analýzou, ktorej kritériom významnosti bola hodnota 1 smerodajnej odchýlky (SD). Ak bol medzi hráčskymi pozíciami zistený rozdiel rovnaký alebo väčší ako hodnota SD priemernej úrovne súboru, tak rozdiel sme považovali za vecne významný.

Kritériom hodnotenia úrovne akceleračnej rýchlosti bol dosiahnutý čas na vzdialenost' $10 \mathrm{~m}$. V štúdii vyhodnocujeme úroveň akceleračnej rýchlosti v čase s presnost’ou $0,01 \mathrm{~s}$.

Kritériom hodnotenia úrovne explozívnej sily dolných končatín bola výška výskoku v cm s presnost'ou 0,1 $\mathrm{cm}$. Zariadenie FiTRO Jumper využíva na výpočet výšky výskoku vzt’ah $\mathrm{h}=(\mathrm{g} \times \mathrm{Tf} 2) / 8$. Výrobca FITRONIC s.r.o. garantuje presnost' a spol'ahlivost' zariadenia overenými simultánnymi meraniami s odrazovou platňou firmy KISTLER.

\section{VÝSLEDKY}

Vyhodnotenie úrovne akceleračnej rýchlosti

Priemerná úroveň akceleračnej rýchlosti súboru bola 2,21 $\pm 0,08 \mathrm{~s}$ (tabul'ka 1). Na základe expertíznej vecnej analýzy sme zistili významne nižšiu úroveň v porovnaní s priemernou výkonnost'ou súboru len u brankárov. U ostatných skupín podl’a hráčskych pozícií sme nezaznamenali významné rozdiely v porovnaní s priemernou úrovňou súboru.

Tab. 1: Priemerná úroveñ akceleračnej rýchlosti hráčov súboru podl'a hráčskych pozícii prezentovaná $v$ bežeckom čase (s)

\begin{tabular}{|l|c|}
\hline Hráčska pozícia & Priemerný čas v behu na 10 m (s) \\
\hline Brankári & $2,31 \pm 0,06 \mathrm{~s}$ \\
\hline Obrancovia & $2,25 \pm 0,05 \mathrm{~s}$ \\
\hline Stredoví hráči & $2,18 \pm 0,10 \mathrm{~s}$ \\
\hline Útočníci & $2,20 \pm 0,06 \mathrm{~s}$ \\
\hline Súbor & $\mathbf{2 , 2 1} \pm \mathbf{0 , 0 8} \mathbf{~ s}$ \\
\hline
\end{tabular}

$v$ - významný rozdiel úrovne akceleračnej rýchlosti skupiny hráčov podl’a hráčskej pozície v porovnani s priemernou úrovňou súboru

Vyhodnotenie úrovne explozívnej sily dolných končatín

Priemerná úroveň explozívnej sily dolných končatín hráčov súboru bola 39,0 44,2 cm. Na základe expertíznej vecnej analýzy sme nezistili významne rozdiely pri porovnaní priemernej úrovne explozívnej sily dolných končatín hráčskych skupín podl’a pozícií s priemernou úrovňou súboru (tabul'ka 2). 
Tab. 2: Priemerná úroveň explozívnej sily dolných končatín hráčov súboru podla hráčskych pozícii prezentovaná výškou vertikálneho výskoku (cm)

\begin{tabular}{|l|c|}
\hline Hráčska pozícia & Vertikálny výskok s protipohybom paží (cm) \\
\hline Brankári & $39,2 \pm 4,0 \mathrm{~cm}$ \\
\hline Obrancovia & $39,6 \pm 5,4 \mathrm{~cm}$ \\
\hline Stredoví hráči & $38,0 \pm 3,8 \mathrm{~cm}$ \\
\hline Útočníci & $39,9 \pm 4,8 \mathrm{~cm}$ \\
\hline Súbor & $\mathbf{3 9 , 0} \pm \mathbf{4 , 2} \mathbf{~ c m}$ \\
\hline
\end{tabular}

\section{DISKUSIA}

Súhlasíme s tvrdeniami, ktoré uvádzajú Reilly, Bangsbo \& Franks (2000), že futbalisti nemusia disponovat' mimoriadnou výkonnost'ou v ktorejkol'vek oblasti fyzickej výkonnosti, ale musia mat' primeranú vysokú úroveň v rámci všetkých oblastí. Bunc \& Psotta (2001) poznamenávajú, že fyziologické predpoklady a normy sú nevyhnutnými podmienkami pre úspech na vrcholovej úrovni, ak ked' nie postačujúcimi. Akceleračná rýchlost' a explozívna sila dolných končatín patria vo futbale $\mathrm{k}$ limitujúcim pohybovým predpokladom dosahovania špičkovej hernej výkonnosti na svetovej úrovni. Z hl’adiska komparácie úrovne akceleračnej rýchlosti u jednotlivých hráčskych pozícií dosiahli v našej štúdii najlepší čas prekvapujúco stredoví hráči $(2,18 \pm 0,10 \mathrm{~s})$. Sporis et al. (2009) zistili u elitných chorvátskych futbalistov $(n=270)$ v sezónach 2005/2006 a 2006/2007, že z hl'adiska akceleračnej bežeckej rýchlosti na 5, 10 a 20 m dosahovali najvyššiu výkonnost' útočníci. Na druhej strane je potrebné konštatovat', že pri porovnaní skupín podl'a hráčskych pozícií sme nezaznamenali významné rozdiely hráčov v poli v porovnaní so súborom. Uvedený čas našich stredových hráčov bol v porovnaní s obrancami lepší len o 3,2 \% a útočníkmi o 0,9 \%. Významne nižšiu úroveň akceleračnej rýchlosti v porovnaní

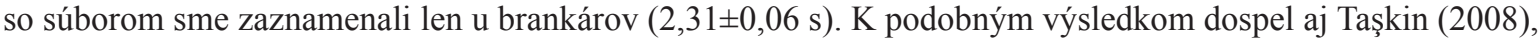
ktorý u profesionálnych futbalistov $(n=243)$ nezistil významné rozdiely $(\mathrm{p}>0,05)$ medzi skupinami hráčov podl'a hráčskych pozícií, aj ked' išlo o bežeckú rýchlost' na $30 \mathrm{~m}$. Podobne aj Rampinini, Sassi \& Impellizzeri (2003) nezistili významné rozdiely $(\mathrm{p}>0,05)$ medzi skupinami obrancov, stredových hráčov, útočníkov a brankárov profesionálnej aj amatérskej úrovne $(\mathrm{n}=78$, vek $=21,0 \pm 4,9$ rokov $)$ z hladiska bežeckej rýchlosti na $30 \mathrm{~m}$.

Malý et al. (2011) zistili u českých futbalových reprezentantov U $16(\mathrm{~N}=23)$ v behu na $10 \mathrm{~m}$ na povrchu

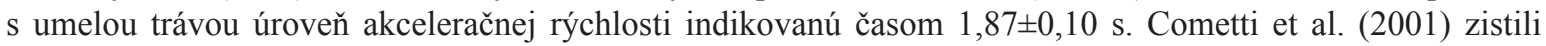
u francúzskych prvoligových hráčov $(\mathrm{n}=29)$ v behu na $10 \mathrm{~m}$ na povrchu s prírodnou trávou priemernú úroveň akceleračnej rýchlosti indikovanú časom $1,80 \pm 0,06 \mathrm{~s}$. Rovnako na prírodnej tráve zistili Dauty, Bryand \& Potiron-Josse (2002) u hráčov $(\mathrm{n}=20$, vek $=23,5 \pm 3,7$ roka) prvoligového francúzskeho tímu FC Nantes priemernú výkonnost' v behu na $10 \mathrm{~m}$ s hodnotou $1,82 \pm 0,08$. Strudwick, Reilly \& Doran (2002) zistili u hráčov tímu anglickej Premier League $(\mathrm{n}=19$, vek $=22,0 \pm 2,0$ roka) priemernú výkonnost' indikovanú časom $1,75 \pm 0,08 \mathrm{~s}$. Wisløff et al. (2004) zistili u hráčov elitného nórskeho družstva Rosenborg FC Trondheim ( $\mathrm{n}=17$, vek $=25,8 \pm 2,9$ rokov) úroveň akceleračnej rýchlosti $1,82 \pm 0,30 \mathrm{~s}$. Meranie bolo realizované v halovej obuvi na parketovej podlahe. V našej štúdii sme zistili úroveň akceleračnej rýchlosti na $10 \mathrm{~m}$ indikovanú časom $2,21 \pm 0,08$ s. Zistený čas je však ovplyvnený skutočnost’ou, že hráči nášho súboru štartovali na zvukový podnet. $\mathrm{Na}$ výslednom výkone $\mathrm{v}$ našom teste sa podiel'ala aj reakčná rýchlost', čo vychádza z požiadaviek hry. Na druhej strane je však potrebné poznamenat', že väčšina podnetov v hre je vizuálneho charakteru. Potrebné je tiež poznamenat', že úroveň bežeckej rýchlosti ovplyvňuje aj správna bežecká technika, ktorá je podmienená kvalitou a charakterom dlhodobého tréningového procesu a športovej prípravy.

Z hl'adiska explozívnej sily dolných končatín sme nezaznamenali významne rozdiely jednotlivých skupín podl’a hráčskych pozícií v porovnaní so súborom. Najvyššiu úroveň sme zaznamenali u útočníkov $(39,9 \pm 4,8$ cm). Sporis et al. (2009) v súlade s výsledkami našej štúdie zistili, že z hráčov v poli dosahovali najvyššiu úroveň explozívnej sily dolných končatín útočníci. Celkovo však bola v štúdii Sporis et al. (2009) najvyššia úroveň explozívnej sily dolných končatín zaznamenaná u brankárov. Úroveň explozívnej sily dolných končatín útočníkov bola $v$ našej štúdii vyššia v porovnaní s obrancami o 0,8 \%, brankármi o 1,6 \% a stredovými hráčmi o 4,8 \%. V d'alších štúdiách zistili Lago-Peñas et al. (2011) zistili u mladých futbalistov $(\mathrm{n}=321$, vek $=$ $15,63 \pm 1,82$ rokov) najlepšie výkony pri vertikálnych skokoch u brankárov a stredných obrancov. Boone et al. (2012) zistili u dospelých hráčov $(n=289)$ šiestich tímov najvyššej belgickej sút'aže priemernú výkonnost' (squat jump $=40,7 \pm 4,6 \mathrm{~cm}$ a countermovement jump $=43,1 \pm 4,9 \mathrm{~cm}$. Z hl'adiska rozdelenia hráčov do skupín 
podl'a hráčskych pozícií dosiahli v súlade s výsledkami štúdie Lago-Peñas et al. (2011) najvyššiu výkonnost' brankári a strední obrancovia v porovnaní so skupinou všetkých obrancov, stredovými hráčmi a útočníkmi. Útočníci zaznamenali vyššiu výkonnost' ako stredoví hráči a obrancovia, čo je v súlade s výsledkami našej štúdie. Haugen et al. (2013) zistili u nórskych hráčov vrátane seniorských a juniorských reprezentantov (n $=$ 939 , vek $=22,1 \pm 4,3$ rokov) za obdobie rokov 1995-2010 pri vertikálnych výskokoch významne nižšiu $(\mathrm{p}<$ $0,05)$ výkonnost' stredových hráčov v porovnaní s ostatnými skupinami pol’a hráčskych pozícií. Gil et al. (2007) konštatujú najvyššiu výkonnost' útočníkov vo všetkých sledovaných parametroch vytrvalosti, rýchlosti, agility a explozívnej sily dolných končatín. Autori však uvádzajú, že nešlo o elitných mladých futbalistov ( $\mathrm{n}=241$, vek $=17,31 \pm 2,64$ rokov). Wisløff, Helgerud \& Hoff (1998) zistili u hráčov elitnej nórskej sút’aže významne vyššiu úroveň explozívnej sily dolných končatín u obrancov a útočníkov v porovnaní so stredovými hráčmi. Mujika et al. (2009) nezistili rozdiely ( $>$ > 0,05) medzi výškou vertikálnych výskokov elitných seniorských futbalistov a elitných mladých futbalistov. Gissis et al. (2006) porovnávali výkonnost' mladých futbalistov (n = 54) rozdelených do skupiny mládežníckeho reprezentačného výberu Grécka, skupiny výkonnostných mladých futbalistov a skupiny rekreačných futbalistov. Z hl’adiska vertikálnych výskokov boli pozorované rozdiely $(\mathrm{p}<$ $0,05)$ medzi reprezentačnou skupinou a ostatnými skupinami. Medzi výkonnostnými a rekreačnými mladými futbalistami neboli pri hodnotení vertikálnych výskokov zaznamenané rozdiely. Kalapotharakos et al. (2006) porovnávali tri tímy $(\mathrm{n}=19$, vek $=26 \pm 4$ rokov, $\mathrm{n}=15$, vek $=24 \pm 4$ rokov, $\mathrm{n}=20$, vek $=23 \pm 3$ rokov) najvyššej gréckej futbalovej sút'aže z hl'adiska viacerých antropometrických a kondičných parametrov. Zistili, že tolerancia laktátu, izokinetická sila extenzorov kolena a výkonnost' pri realizácii vertikálnych výskokov vykazovali vyššie hodnoty $(\mathrm{p}<0,05) \mathrm{u}$ tímu, ktorý patril $\mathrm{k}$ trom najlepším družstvám najvyššej sútaže v porovnaní s hodnotami sledovaných parametrov družstiev, ktoré boli v strede a medzi poslednými tímami sútaže. Wong \& Wong (2009) zistili u ázijských mladých hráčov $(\mathrm{n}=16$, vek $=16,2 \pm 0,6$ rokov) nižšiu výkonnost' vo vertikálnych výskokoch v porovnaní s európskymi a africkými hráčmi. V d’alších štúdiách zistili Arnason et al. (2004) u elitných islandských futbalistov výšku výskoku $\mathrm{SJ}=37,8 \mathrm{~cm}$ a $\mathrm{CMJ}=39,4 \mathrm{~cm}$. Casajüs (2001) zistil u španielskeho elitného tímu $(n=15)$ výšku výskoku pri $S J=39 \mathrm{~cm}$ a pri CMJ s použitím paží $=47,8 \mathrm{~cm}$.

Z hl'adiska požiadaviek hry predstavuje vysoká úroveň explozívnej sily dolných končatín výhodu v osobných vzdušných súbojoch, ale aj v bežeckom a celkovom komplexnom rýchlostnom prejave futbalistu, čo dokazujú aj výskumy Wisløff et al. (2004), ktorí dokázali významnú koreláciu šprintu na 10 a 30 m a vertikálnymi skokmi u elitných medzinárodných futbalistov ( $\mathrm{n}=17$, vek $=25,8 \pm 2,9$ rokov).

Nevyhnutné je spomenút' aj limity realizovaného výskumu. Predmetom štúdie bola priamočiara akceleračná rýchlost' na $10 \mathrm{~m}$ a nešpecifický test explozívnej sily dolných končatín. Výkon v priamočiarom šprinte a taktiež vertikálny výskok v podmienkach izolovaných od hry sú len určitými predpokladmi, pretože herný prejav futbalistu je ovplyvnený variabilitou špecifických herných podmienok a aktuálnych požiadaviek hry. Špecifická herná lokomócia sa prejavuje zmenami frekvencie, zmenami dížky kroku a taktiež zmenami smeru behu, pretože hráč je nútený neustále upravovat' svoj priamočiary pohyb na základe vnímania vonkajších podmienok. Ide napríklad o súčinnost' so spoluhráčmi, vnímanie protihráčov a realizáciu bežeckého šprintu s loptou. Rovnako pri realizácii strel'by je hráč nútený prispôsobovat' techniku šprintu pred strel'bou. $Z$ uvedených dôvodov by bolo budúcnosti vhodné vytvorit' špecifické terénne testy, ktoré budú herne validné pre akceleračnú rýchlost'a explozívnu sily dolných končatín a komparovat' ich s testami, ktoré prezentujeme v predloženej štúdii. Rovnako určitým obmedzením je jednorazové testovanie a s tým spojené obmedzenie v súvislosti so spol’ahlivost'ou. Jednorazové meranie môže byt' ovplyvnené vonkajšími podmienkami, ale aj aktuálnymi vnútornými dispozíciami testovaného. Vychádzali sme však z časovo limitovaných organizačných možností programu futbalovej reprezentácie U21. Ďalším limitom je skutočnost', že zistené výsledky neboli interpretované vo vzt'ahu k morfológii hráčov a taktiež by bolo potrebné posudzovat' aj techniku behu. Limitom predovšetkým vo vzt'ahu k zovšeobecneniu výsledkov je početnost' súboru. Na objektívne vedecké zistenie rozdielov medzi výkonnost'ou z hl'adiska skúmaných pohybových schopností u jednotlivých hráčskych pozícii by bolo potrebné realizovat' výskum na početnejšej vzorke futbalistov. Nedostatočný počet hráčov v každej z komparovaných skupín (najmä zaradeniu len dvoch brankárov) spôsobuje, že vzt’ahy medzi hráčskymi pozíciami sa týkajú len nášho súboru futbalových reprezentantov Slovenskej republiky U21. Z tohto dôvodu sme na zistenie rozdielov úrovne skúmaných pohybových schopností nepoužili žiaden test štatistickej významnosti rozdielov a použili sme len expertíznu vecnú analýzu.

Z hl'adiska požiadaviek moderného futbalu existujú rozdiely $\mathrm{v}$ hre a teda aj $\mathrm{v}$ požiadavkách $\mathrm{z}$ hl'adiska individuálneho herného výkonu u krajných a stredných obrancov a v závislosti od taktických variantov aj u 
krajných a stredných stredových hráčov. V našej štúdii sa však jednalo o mladých hráčov, z ktorých niektorí alternovali (posuny v rámci obrannej aj stredovej línie). Ked’že sa navyše jedná o mladých futbalistov s možnost'ou zmeny hráčskej pozície $\mathrm{v}$ budúcnosti, tak v predloženej štúdii sme analýzu úrovne skúmaných pohybových schopností nediferencovali na prioritne stredných a alternujúcich stredných, resp. krajných obrancov a taktiež krajných a stredných stredových hráčov.

Prezentovaná štúdia aj napriek uvedeným limitom môže byt' inšpiráciou pre kondičných a atletických trénerov futbalových družstiev, aby odhal'ovali a odstraňovali slabé stránky svojich zverencov predovšetkým v kondičných tréningoch $\mathrm{v}$ prípravných obdobiach a individuálnych tréningoch podl'a aktuálnych výsledkov diagnostík počas celého ročného tréningového cyklu. Predložené dáta môžu tiež slúžit' ako určitá norma alebo štandard elitných mládežníckych futbalistov z hl'adiska úrovne skúmaných pohybových schopností. Výsledky štúdie môžu byt' cenným materiálom pre vedeckých pracovníkov, ale aj pre trénerov, odborníkov a záujemcov o futbal.

\section{ZÁVERY}

Priemerná úroveň akceleračnej rýchlosti hráčov súboru slovenskej futbalovej reprezentácie U21 bola 2,21 $\pm 0,08$ s. Expertízna vecná analýza ukázala, že pri porovnaní úrovne akceleračnej rýchlosti hráčov skupín podl'a hráčskych pozícií v poli sa nevyskytli významné rozdiely. Najvyššia úroveň akceleračnej rýchlosti bola zaznamenaná u stredových hráčov s hodnotou $2,18 \pm 0,10 \mathrm{~s}$, potom u útočníkov s hodnotou 2,20 $\pm 0,06$ $\mathrm{s}$ a obrancov $2,25 \pm 0,05 \mathrm{~s}$. Významne nižšiu úroveň akceleračnej rýchlosti sme zaznamenali u len u skupiny brankárov s hodnotou 2,31 $\pm 0,06 \mathrm{~s}$.

Priemerná úroveň explozívnej sily dolných končatín hráčov súboru bola indikovaná hodnotou 39,0 44,2 $\mathrm{cm}$ pri teste vertikálneho výskoku. Expertízna vecná analýza neukázala rozdiely medzi skupinami hráčov podl’a hráčskych pozícií. Najvyššia úroveň explozívnej sily dolných končatín bola zaznamenaná u útočníkov $\mathrm{s}$ hodnotou $39,9 \pm 4,8 \mathrm{~cm}$, potom u obrancov s hodnotou $39,6 \pm 5,4 \mathrm{~cm}$, u brankárov $39,2 \pm 4,0 \mathrm{~cm}$ a stredových hráčov $38,0 \pm 3,8 \mathrm{~cm}$.

\section{LITERATÚRA}

Andrzejewski, M., Chmura, J., Pluta, B., Strzelczyk \& Kasprzak, A. (2012). Analysis of sprinting activities of professional soccer players. Journal of Strength and Conditioning research / National Strength \& Conditioning Association, 27, 2134-2140.

Arnason, A. Siqurdsson, S. B., Gudmundsson, A., Holme, I., Engebretsten, L. \& Bahr, R. (2004). Physical Fitness, Injuries, and Team Performance in Soccer. Medicine and Science in Sports and Exercise, 36(2), 278285.

Bangsbo, J., Mohr, M. \& Krustrup, P. (2006). Physical and metabolic demands of training and match-play in the elite football player. Journal of sport sciences, 24(7), 665-674.

Bangsbo, J., Iaia, F. M. \& Krustrup, P. (2007). Metabolic response and fatigue in soccer. International journal of sports physiology and performance, 2(2), 111-127.

Boone, J., Vaeyens, R., Steyaert, A., Vanden Bossche, L., \& Bourgois, J. (2012). Physical fitness of elite Belgian soccer players by player position. Journal of Strength and Conditioning research / National Strength \& Conditioning Association, 26, 2051-2057.

Bunc, V. (1999). Role kondice v př́pravě hráče fotbalu. Fotbal a trénink, 5, 20-21.

Bunc, V. \& Psotta, R. (2001). Physiological profile of very young soccer players. The Journal of Sports Medicine and Physical Fitness, 41(3), 337-341.

Casajüs, J. A. (2001). Seasonal variation in fitness variables in professional soccer players. Journal of Sports Medicine and Physical Fitness, 41(4), 463-469.

Cometti, G., Maffiuletti, N. A., Pousson, M., Chatard, J.-C. \& Maffulli, N. (2001). Isokinetic strength and anaerobic power of elite, subelite and amateur French soccer players. International Journal of Sports Medicine, $22,45-51$.

Dauty, M., Bryand, F. \& Potiron-Josse. M. (2002). Relation entre la force isocinétique, le saut et le sprint chez le footballeur de haut niveau. Science and Sports, 17(3), 122-127.

Gissis, I., Papadopoulos, C., Kalapotharakos, V. I., Sotiropoulos, A., Komsis, G. \& Manolopoulos, E. (2006). Strength and speed characteristics of elite, subelite, and recreational young soccer players. Research in Sports 
Medicine, 14, 205-214.

Grasgruber, P. \& Cacek, J. (2008). Sportovní geny. Brno : FSS MU.

Haugen, T. A., Tønnessen, E. \& Seiler, S. (2013). Anaerobic Performance Testing of Professional Soccer Players 1995-2010. Internalitonal journal of sports physiology and performance, 8(2), 148-156.

Hipp, M. (2007). Futbal. Rozvoj vybraných pohybových schopností, diagnostika a strečing $v$ družstve vrcholového futbalu. Bratislava: SPN.

Jančoková, L'. (2000). Biorytmy v športe (S úvodom do chronobiológie). Banská Bystrica : FHV UMB.

Kalapotharakos, V. I., Strimpakos, N., Vithoulka, I., Karvounidis, C., Diamantopoulos, K., \& Kapreli, E. (2006). Physiological characteristics of elite professional soccer teams of different ranking. The Journal of sports medicine and physical fitness, 46, 515-519.

Little, T. \& Williams, A. G. (2006). Effects of differential stretching protocols during warm-ups on high-speed motor capacities in professional soccer players. Journal of Strength and Conditioning Research, 20, 203-207.

Malý, T., Zahálka, F., Malá, L., Buzek, M., Hrásky, P. \& Gryc, T. (2011). Vzt’ah izokinetickej sily dolných končatín k rýchlostným indikátorom bežeckej rýchlosti mladých futbalistov. Česká kinantropologie, 15(3), 157-164.

Nemec, M., Štefaňák, P. \& Sylvestr, M. (2005). Tréner futbalu. Učebné texty pre trénerov futbalu C licencie. Banská Bystrica : SsFZ TMK.

Orendurff, M. S., Walker, J. D., Jovanovic, M., Tulchin, K. L., Levy, M. \& Hoffmann, D. K. (2010). Intensity and duration of intermittent exercise and recovery during a soccer match. Journal of Strength and Conditioning research / National Strength \& Conditioning Association, 24(10), 2683-2692.

Psotta, R., Bunc, V., Netscher, J., Mahrová, A. \& Nováková, H. (2006). Fotbal-kondiční trénink. Praha : Grada. Rampinini, E., Sassi, A. \& Impellizzeri, F. M. (2003). Sprint and jump abilities in soccer players of different positions. Salzburg : Communication to: European College of Sport Science Congress.

Reilly, T. (1997). Energetics of high-intensity exercise (soccer) with particular reference to fatigue. J Sports Sci., 15(3), 257-263.

Reilly, T. Bangsbo, J. \& Franks, A. (2000). Anthropometric and physiological predispositions for elite soccer. Journal of sports sciences, 18(9), 669-683.

Sporis, G., Jukic, I., Ostojic, S. M., \& Milanovic, D. (2009). Fitness profiling in soccer: physical and physiologic characteristics of elite players. Journal of Strength and Conditioning research / National Strength \& Conditioning Association, 23, 1947-1953.

Strudwick, A., Reilly, T. \& Doran, D. (2002). Anthropometric and fitness profiles of elite players in two football codes. Journal of Sports Medicine and Physical Fitness, 42(2), 239-242.

Taşkin, H. (2008). Evaluating sprinting ability, density of acceleration, and speed dribbling ability of professional soccer players with respect to their positions. Journal of Strength and Conditioning Research, 22, 1481-1486.

Weineck, J. (2007). Optimales Training : leistungsphysiologische Trainingslehre unter besonderer Berücksichtigung des Kinder- und Jugendtrainings. Balingen : Spitta Verlag GmbH \& Co. KG.

Wisløff, U., Helgerud, J. \& Hoff, J. (1998). Strength and endurance of elite soccer players. Medicine and Science in Sports and Exercise, 30(3), 462-467.

Wisløff, U., Castagna, C., Helgerud, J., Jones, R. \& Hoff, J. (2004). Strong correlation of maximal squat strength with sprint performance and vertical jump height in elite soccer players. British Journal of Sports Medicine, 38, 285-288.

Wong, D. P. \& Wong, S. H. S. (2009). Physiological profile of Asian elite youth soccer players. Journal of Strength and Conditioning research / National Strength \& Conditioning Association, 23, 1383-1390. 